\title{
TABUNGAN PERUMAHAN RAKYAT (TAPERA) DAN PENERAPANNYA DI DKI JAKARTA
}

\author{
Henriko Ganesha Putra ${ }^{1}$, Erwin Fahmi ${ }^{2}$, Kemal Taruc ${ }^{3}$ \\ ${ }^{1}$ Program Studi Perencanaan Wilayah dan Kota, Universitas Tarumanagara \\ Email: budi@untx.ac.id \\ ${ }^{2}$ Program Studi Perencanaan Wilayah dan Kota, Universitas Tarumanagara \\ Email:sinta@unty.co.id \\ ${ }^{3}$ Program Studi Perencanaan Wilayah dan Kota, Universitas Tarumanagara \\ Email:doni@gmail.com
}

Masuk: 23-09-2019, revisi: 07-01-2020, diterima untuk diterbitkan: 10-01-2020

\begin{abstract}
ABSTRAK
Hunian merupakan kebutuhan dasar setiap manusia. Sebagaimana amanat UUD 1945, Negara menjamin pemenuhan kebutuhan warga negara atas tempat tinggal yang layak dan terjangkau dalam rangka membangun manusia Indonesia seutuhnya, berjati diri, mandiri, dan produktif. Tabungan Perumahan Rakyat (Tapera) sesuai UndangUndang Republik Indonesia nomor 4 tahun 2016, merupakan program penyimpanan dana jangka panjang yang dimanfaatkan untuk pembiayaan perumahan, terutama bagi Masyarakat Berpenghasilan Rendah (MBR). BAPERTARUM-PNS menjadi pelajaran penting bagaimana ketidakberhasilan tujuan dari tabungan perumahan yang dimanfaatkan sebagai tabungan pensiun oleh sebagian besar peserta. Permasalahan dari studi ini adalah apakah Tapera dapat menjadi solusi bagi MBR dalam menjangkau pembiayaan untuk memperoleh hunian atau mengulangi ketidakberhasilan program BAPERTARUM-PNS. Pengumpulan data dari Pemerintah Pusat, BP Tapera, dan Pemerintah Provinsi DKI Jakarta akan dianalisis dalam bentuk Pemodelan potensi kepesertaan dan dana pemanfaatan Tapera secara nasional maupun regional di Provinsi DKI Jakarta. Hasil dari analisis pemodelan tersebut mengindikasikan adanya celah (gap) antara kebijakan Tapera dan harapan masyarakat akan hadirnya solusi keterjangkauan pembiayaan hunian bagi MBR.
\end{abstract}

Kata kunci: Tapera; Hunian; MBR; BAPERTARUM-PNS; DKI Jakarta

\section{ABSTRACT}

Occupancy is a basic need of every human being. As mandated by the 1945 Constitution, the State guarantees the fulfillment of citizens' needs for decent and affordable dwellings in the framework of developing Indonesian people who are wholly, self-conscious, independent and productive. The Public Housing Savings (Tapera) in accordance with Law of the Republic of Indonesia number 4 of 2016, is a long-term fund storage program that is used for housing finance, especially for Low-Income Communities (MBR). BAPERTARUM-PNS is an important lesson on how the goals of the housing savings are not utilized as retirement savings by most participants. The problem with this study is whether Tapera can be a solution for MBR in reaching funding for housing or repeating the failure of the BAPERTARUM-PNS program. Data collection from the Central Government, BP Tapera, and the Provincial Government of DKI Jakarta will be analyzed in the form of modeling of potential national and regional participation in and utilization of Tapera in DKI Jakarta Province. The results of the modeling analysis indicate a gap between Tapera's policies and people's expectations of a housing finance affordability solution for the MBR.

Keywords: Tapera; Occupancy; MBR; BAPERTARUM-PNS; DKI Jakarta 


\section{PENDAHULUAN}

\section{Latar Belakang}

Hunian merupakan kebutuhan dasar setiap manusia sebagai tempat berlindung dan sarana pembinaan keluarga (Mashlow, 1954). Menurut data resmi pemerintah, kebutuhan hunian yang belum terlayani (backlog) tahun 2016 mencapai 11,4 juta rumah tangga, dan yang terbesar terdapat di Provinsi DKI Jakarta, yakni sebanyak 49,84\% dari jumlah tersebut (Kementerian Pekerjaan Umum dan Perumahan Rakyat Republik Indonesia, RETalks\#4 Untar: 27 September 2018).

Sistem ekonomi perkotaan yang kapitalistik menjadikan rumah sebagai sebuah produk yang diproduksi untuk dijual di pasar dan bukan lagi sebagai produk yang dihasilkan oleh komunitas untuk memenuhi kebutuhan anggotanya. Kapitalisasi sistem perumahan tidak diiringi oleh kesiapan masyarakatnya yang sebagian besar masih bekerja secara informal dan tidak terintegrasi dalam sistem kota. Ini jelas dapat diamati justru di kota-kota besar yang ekonominya berkembang paling pesat dan penduduknya mempunyai pendapatan per kapita paling tinggi, permasalahan perumahannya paling besar. Mengapa demikian? Karena semakin besar kapital yang ditanamkan di sebuah kota, semakin cepat juga terjadi transformasi sistem penyediaan perumahan (Santoso, 2002). Pemerintah telah berupaya hadir dan memberikan solusi terhadap persoalan kebutuhan masyarakat akan hunian. Hunian tidak bisa lagi semata menjadi obyek kompetisi bebas bagi masyarakat; Pemerintah hadir untuk memberikan Perlindungan dan Jaminan Sosial Perumahan bagi seluruh masyarakat Indonesia.

Tabungan Perumahan Rakyat (Tapera) sesuai amanat Undang-Undang Republik Indonesia nomor 4 tahun 2016 merupakan program penyimpanan dana jangka panjang yang dimanfaatkan untuk pembiayaan perumahan, terutama bagi MBR. Namun demikian, apabila kita menelaah dari naskah akademik Rancangan Undang-Undang tentang Tapera dan Undang-Undang Tapera nomor 4 tahun 2016 tersebut, terdapat celah substantif (loopholes) yang mengindikasikan program Tapera bisa mengulangi kegagalan program terdahulu, Bapertarum-PNS.

Harapannya Tapera dapat menjadi solusi bagi warga negara Indonesia dalam menjangkau pembiayaan untuk memperoleh hunian. Namun, sejauhmana Tapera dapat diaplikasikan secara nasional, mengingat setiap kota/daerah memiliki masalah dan strategi yang berbeda dalam sistem penyediaan perumahan? Studi ini akan menelaah hal tersebut, dengan menjadikan DKI Jakarta sebagai lokus exercise aplikasi model Tapera.

\section{Rumusan Masalah}

Keterjangkauan pembiayaan perumahan menjadi salah satu masalah kepemilikan rumah, terutama bagi MBR, di Indonesia. Tapera bertujuan menghimpun dan menyediakan dana murah jangka panjang untuk pembiayaan perumahan. Karena itu, Tapera diharapkan menjadi solusi keterjangkauan pembiayaan perumahan. Tapera dibentuk untuk menyempurnakan program terdahulu, Bapertarum-PNS, yang fungsinya kurang optimal. Bapertarum-PNS memiliki konsep yang baik, yakni pembiayaan perumahan yang berasal dari partisipasi tabungan masyarakat, sehingga tidak hanya mengandalkan subsidi pemerintah. Melalui Tapera, skala partisipasi diperluas tidak hanya bagi PNS (Pegawai Negeri Sipil), namun juga bagi semua pekerja dan pekerja mandiri di seluruh Indonesia. Karena itu, studi ini akan mengkaji sejauhmana Tapera menjadi solusi bagi terjangkaunya biaya perumahan bagi MBR, ataukah akan kembali mengulangi kegagalan program terdahulu? 


\section{Tujuan Penelitian}

Memahami konsep dan model Tapera sebagai program penyimpanan dana jangka panjang yang dimanfaatkan untuk pembiayaan perumahan, terutama bagi MBR serta implikasinya terhadap kebutuhan perumahan secara nasional dan regional di DKI Jakarta.

\section{METODE PENELITIAN}

Penelitian ini menggunakan metode kualitatif-deskriptif. Pendekatan kualitatif deskriptif bertujuan mendekripsikan secara sistematis dan faktual skema pengelolaan dana yang meliputi pengerahan, pemupukan, dan pemanfaatan dana Tapera (Gulo, 2010). Data dikumpulkan melalui wawancara dan dokumen pendukung dari berbagai informan, diantaranya Kementerian Pekerjaan Umum dan Perumahan Rakyat (KemenPUPR), Badan Pengelola Tabungan Perumahan Rakyat (BP Tapera), serta Dinas Perumahan dan Kawasan Permukiman DKI Jakarta. Data-data tersebut dianalisis dengan pendekatan kualitatif. Analisis dilakukan secara bersamaan dengan tahap pengumpulan data, tahap pendalaman (probing) dan verifikasi melalui triangulasi. Proses ini bermuara pada kategorisasi, klasifikasi, dan ditemukannya pola-pola atau konstruksi sosial tertentu beserta penjelasannya (Fahmi, 2018).

Analisis yang dilakukan dalam penelitian ini adalah:

a. Analisis terhadap penerapan program bantuan pembiayaan perumahan BAPERTARUM-PNS;

b. Analisis terhadap pola dan mekanisme pengerahan, pemupukan, dan pemanfaatan dana tabungan perumahan yang akan diterapkan secara nasional;

c. Analisis terhadap aplikasi pola, mekanisme dan kelayakan tabungan perumahan tersebut di propinsi DKI Jakarta sebagai studi kasus.

\section{HASIL DAN PEMBAHASAN}

\section{Regulasi Tapera}

Undang Undang Republik Indonesia Nomor 4 Tahun 2016 tentang Tabungan Perumahan Rakyat merupakan pedoman umum terkait Tapera. Sedangkan regulasi yang berkaitan dengan pedoman pelaksanaan operasional Tapera berupa Peraturan Pemerintah dan Peraturan BP Tapera, sampai studi ini berlangsung (Agustus 2019), masih dalam proses penyusunan dan/atau pengesahan.

\section{Evaluasi Bantuan Perumahan BAPERTARUM-PNS}

BAPERTARUM-PNS didirikan berdasarkan Keputusan Presiden RI Nomor 14 Tahun 1993 tentang Tabungan Perumahan Pegawai Negeri Sipil, sebagaimana telah diubah dengan Keputusan Presiden Nomor 46 Tahun 1994. Dilatarbelakangi oleh terbatasnya kemampuan PNS untuk membayar uang muka pembelian rumah dengan fasilitas Kredit Pemilikan Rumah (KPR) maka didirikan BAPERTARUM-PNS. Institusi ini bertujuan untuk meningkatkan kesejahteraan PNS untuk memiliki rumah yang layak.

Tabel 1. Penyaluran Produk Layanan BAPERTARUM-PNS tahun 1993 - Maret 2018

\begin{tabular}{llrr}
\hline \multirow{2}{*}{ No } & \multirow{2}{*}{ Produk } & \multicolumn{2}{c}{1993 s.d Maret 2018 } \\
\cline { 3 - 4 } & & \multicolumn{1}{c}{ PNS } & \multicolumn{1}{c}{ Rp.(M) } \\
\hline 1 & BUM & 533.245 & 912,33 \\
\hline 2 & BM & 472.703 & 820,85 \\
\hline 3 & BTP & 18.168 & 71,69 \\
\hline 4 & PT & 1.615 .527 & $1.752,98$ \\
\hline 5 & TBUM/TBM & 1.467 & 25,39 \\
\hline 6 & PUM/PBM/PUM Rusun & 9.385 & 81,27 \\
\hline 7 & PLBA-PR & 18.674 & 174,17 \\
\hline \multicolumn{3}{c}{ Jumlah Penyaluran } & 2.669 .169 \\
\hline \multicolumn{3}{c}{ Sumber: BP Tapera, diolah oleh Penulis, 2019} \\
\hline
\end{tabular}


Keterangan :

$\begin{array}{ll}\text { BUM } & \text { : Bantuan Uang Muka } \\ \text { BM } & \text { : Bantuan Sebagian Biaya Membangun } \\ \text { BTP } & \text { : Bantuan Tabungan Perumahan } \\ \text { PT } & \text { : Pengembalian Tabungan } \\ \text { TBUM } & \text { : Tambahan Bantuan Uang Muka } \\ \text { TBM } & \text { : Tambahan Bantuan Sebagian Biaya Membangun } \\ \text { PUM } & \text { : Pinjaman Uang Muka } \\ \text { PBM } & \text { : Pinjaman Sebagian Biaya Membangun } \\ \text { PUM Rusun } & \text { : Pinjaman Uang Muka Rumah Susun } \\ \text { PLBA-PR } & \text { : Pinjaman Lunak Bencana Alam-Perbaikan Rumah }\end{array}$

Hipotesis 1: Produk penyaluran terbesar adalah Pengembalian Tabungan (PT) sebanyak 1.615.527 PNS atau 60,5 \% dari Total Jumlah penyaluran Taperum dari tahun 1993 - Maret 2018 sebanyak 2.669.169 PNS. Ini mengindikasikan bahwa tujuan awal pembentukan Taperum, yakni untuk mengatasi keterbatasan kemampuan PNS dalam membayar uang muka dan KPR tidak berhasil. Sebagian besar PNS ternyata memanfaatkan Taperum ini sebagai tabungan masa tua/pensiun.

\section{MEKANISME PENGELOLAAN DANA TAPERA}

Kepesertaan Tapera menurut Undang Undang no.4 tahun 2016 adalah semua Warga Negara Indonesia (WNI) dan Warga Negara Asing (WNA) pemegang Visa dengan maksud bekerja di wilayah Indonesia paling singkat 6 (enam) bulan yang telah membayar simpanan. Kriteria Peserta Wajib adalah Pekerja maupun Pekerja Mandiri, memiliki penghasilan sekurangkurangnya sebesar Upah Minimum, dan berusia minimum 20 tahun atau sudah menikah. Sedangkan Peserta Sukarela memiliki kriteria Pekerja maupun Pekerja Mandiri, memiliki penghasilan dibawah Upah Minimum, dan berusia minimum 20 tahun atau sudah menikah.

Tabel 2. Mekanisme Penyetoran Simpanan Peserta

\begin{tabular}{|c|c|c|}
\hline Pemberi Kerja : & Pekerja Mandiri : & Bank Kustodian : \\
\hline $\begin{array}{lrr} & \text { Wajib } & \text { membayar } \\
\text { simpanan yang } & \text { menjadi } \\
\text { kewajibannya dan } & \text { memungut } \\
\text { simpanan yang menjadi } \\
\text { kewajiban pekerjanya yang } \\
\text { menjadi peserta; }\end{array}$ & $\begin{array}{l}\text { - Wajib menyetor } \\
\text { sendiri simpanan yang menjadi } \\
\text { kewajibannya ke dalam } \\
\text { rekening peserta yang dikelola } \\
\text { oleh bank Kustodian; }\end{array}$ & 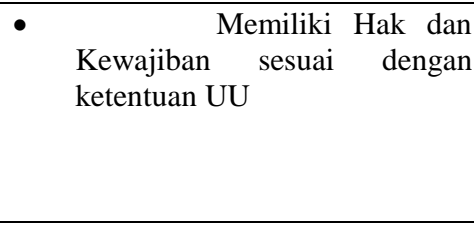 \\
\hline $\begin{array}{l}\text { Wajib menyetor } \\
\text { simpanan ke rekening peserta } \\
\text { yang dikelola oleh Bank } \\
\text { Kustodian; }\end{array}$ & $\begin{array}{l}\text { - } \quad \text { Besar simpanan } 3 \% \\
\text { dari penghasilan. }\end{array}$ & $\begin{array}{l}\text { - } \quad \text { Wajib mencatat } \\
\text { penerimaan simpanan ke setiap } \\
\text { rekening peserta. }\end{array}$ \\
\hline \begin{tabular}{llrr} 
& \multicolumn{3}{r}{ Besar simpanan $3 \%$} \\
dari penghasilan & $(2,5 \%$ \\
dipotong dari penghasilan \\
pekerjanya $+0,5 \%$ dari \\
pemberi kerja).
\end{tabular} & & \\
\hline
\end{tabular}

Sumber: Kementerian PUPR, diolah Penulis,2019

Pemupukan Dana Tapera bertujuan untuk meningkatkan nilai Dana Tapera. Peserta dapat memilih 2 jenis pemupukan, yaitu konvensional dan syariah. Bank Kustodian akan mengeluarkan Kontrak Investasi Dana Tapera Konvensional (KIDT), maupun Kontrak Investasi Dana Tapera Syariah (KIDTs). Pemupukan Dana dilakukan oleh Manajer Investasi melalui 
Produk Keuangan Konvensional dan Syariah yang menguntungkan sesuai ketentuan Undangundang.

Pemanfaatan Dana Tapera akan disalurkan oleh Bank atau Lembaga Keuangan lain kepada Peserta Tapera yang memenuhi syarat. Adapun produk penyaluran dana pemanfaatan Tapera dapat berupa kepemilikan/KPR, pembangunan baru, atau perbaikan/renovasi. Pengerahan dana lain, selain pemupukan dana pemanfaatan adalah cadangan. Dana cadangan ini digunakan untuk pengembalian tabungan peserta yang telah pensiun atau meninggal dunia. Sebelum dilakukan pembayaran, dana akan ditempatkan di deposito.

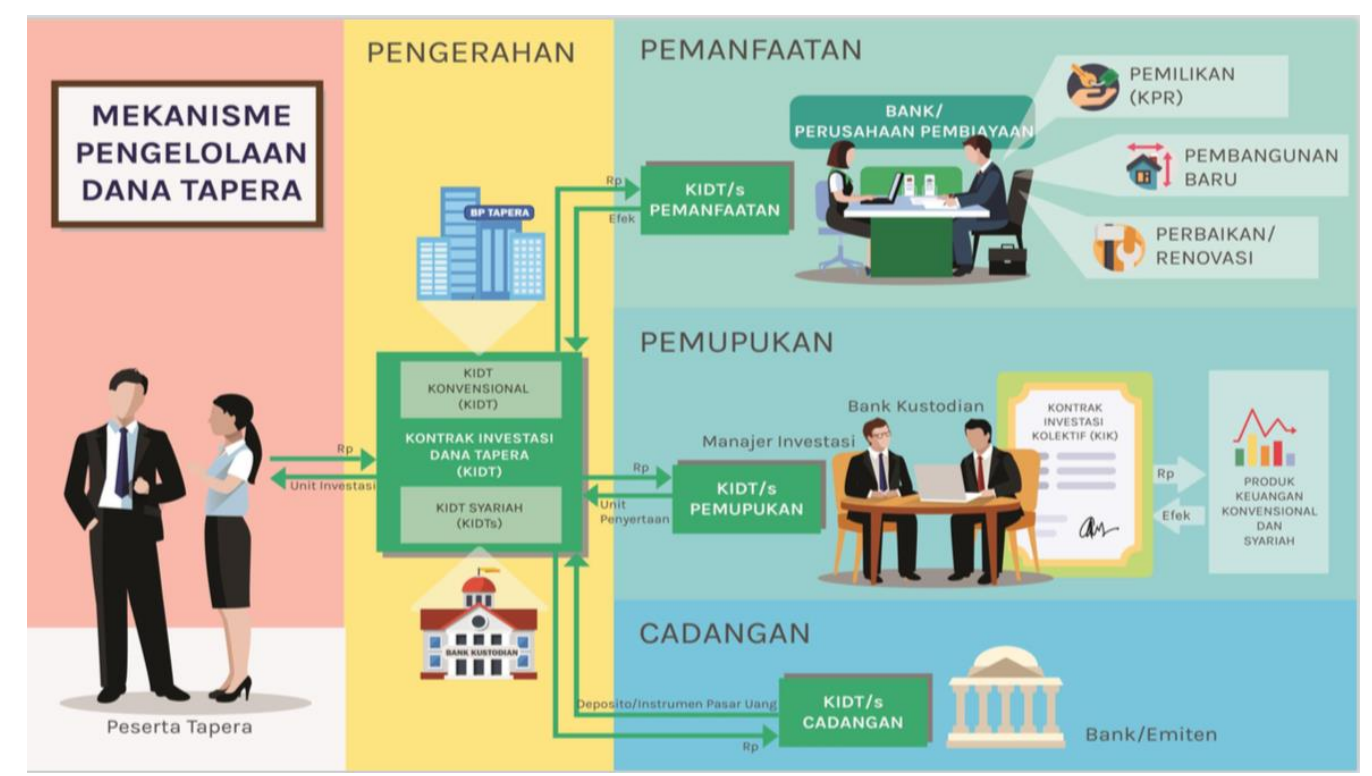

Gambar 1. Mekanisme Pengelolaan Dana Tapera

Sumber: Kementerian Pekerjaan Umum dan Perumahan Rakyat, 2019

\section{Analisis Potensi Kepesertaan, Pengerahan dan Pemanfaatan Dana Tapera secara Nasional}

Menurut KemenPUPR, asumsi yang digunakan adalah sebagai berikut:

a. Pentahapan kepesertaan 10 tahun. Di awal beroperasi: PNS, TNI, Polri dan BUMN peningkatan $3 \%$ per tahun;

b. Jumlah Peserta yang berasal dari PNS, TNI, Polri dan BUMN berasal dari asumsi Kementerian PUPR;

c. Jumlah besar iuran dari peserta yang adalah $3 \%$ dari penghasilan, berasal dari asumsi Kementerian PUPR;

d. Alokasi dana Tapera untuk pemanfaatan: 65\% dari seluruh dana Tapera;

e. Proporsi pemanfaatan pembiayaan perumahan:

- KPR/Kepemilikan: 60\% dari total alokasi dana pemanfaatan (rata-rata harga rumah tapak sejahtera FLPP KepMenPUPR 2016: Rp140 juta);

- Pembangunan rumah baru: 20\% dari total alokasi dana pemanfaatan (maks. Rp80 juta); dan

- Perbaikan maupun peningkatan kualitas rumah: 20\% dari total alokasi dana pemanfaatan (maks.Rp50 juta).

f. Dana Bapertarum-PNS: Rp11 triliun. 
Tabel 3. Potensi Kepesertaan dan Dana Tapera

\begin{tabular}{|c|c|c|c|c|c|c|c|c|c|c|}
\hline & & & & & Tahu & & & & & \\
\hline & 1 & 2 & 3 & 4 & 5 & 6 & 7 & 8 & 9 & 10 \\
\hline PNS (org) & 4.468 .000 & 4.602 .040 & 4.740 .101 & 4.882 .304 & 5.028 .773 & 5.179 .637 & 5.335 .026 & 5.495 .076 & 5.659 .929 & 5.829 .727 \\
\hline TNI/Polri (org) & 841.000 & 866.230 & 892.217 & 918.983 & 946.553 & 974.949 & 1.004 .198 & 1.034 .324 & 1.065 .354 & 1.097 .314 \\
\hline Pekerja Swasta (org) & 647.476 & 666.900 & 686.907 & 707.515 & 728.740 & 750.602 & 773.120 & 796.314 & 820.203 & 844.809 \\
\hline \begin{tabular}{|l} 
Pekerja Mandiri (org) \\
\end{tabular} & 776.920 & 800.228 & 824.234 & 848.961 & 874.430 & 900.663 & 927.683 & 955.514 & 984.179 & 1.013 .704 \\
\hline \begin{tabular}{|l|} 
Total Peserta (org) \\
\end{tabular} & 6.733 .396 & 6.935 .398 & 7.143 .460 & 7.357 .764 & 7.578 .497 & 7.805 .851 & 8.040 .027 & 8.281 .228 & 8.529 .665 & 8.785 .555 \\
\hline \begin{tabular}{|l|} 
Dana Bapertarum - PNS (Rp. triliun) \\
\end{tabular} & 1,1 & 1,1 & 1,1 & 1,1 & 1,1 & 1,1 & 1,1 & 1,1 & 1,1 & 1,1 \\
\hline Simpanan Peserta/tahun (Rp. triliun) & 4,55 & 4,69 & 4,83 & 4,97 & 5,12 & 5,27 & 5,43 & 5,60 & 5,76 & 5,94 \\
\hline Total Simpanan (Rp. triliun) & 5,65 & 5,79 & 5,93 & 6,07 & 6,22 & 6,37 & 6,53 & 6,70 & 6,86 & 7,04 \\
\hline Kumulatif Simpanan (Rp. Triliun) & 5,65 & 11,44 & 17,36 & 23,44 & 29,66 & 36,03 & 42,56 & 49,26 & 56,12 & 63,16 \\
\hline
\end{tabular}

Sumber: Hasil Perhitungan Penulis, 2019

Tabel 4. Potensi Pemanfaatan Dana Tapera

\begin{tabular}{|c|c|c|c|c|c|c|c|c|c|c|}
\hline \multirow{2}{*}{ Biaya } & \multicolumn{10}{|c|}{ Tahun Ke- } \\
\hline & 1 & 2 & 3 & 4 & 5 & 6 & 7 & 8 & 9 & 10 \\
\hline Total Simpanan (trilyun) & 5,65 & 5,79 & 5,93 & 6,07 & 6,22 & 6,37 & 6,53 & 6,70 & 6,86 & 7,04 \\
\hline Alokasi Dana Pemanfaatan (triliun) & 3,67 & 3,76 & 3,85 & 3,95 & 4,04 & 4,14 & 4,25 & 4,35 & 4,46 & 4,57 \\
\hline KPR @Rp.140 juta (triliun) & 2,20 & 2,26 & 2,31 & 2,37 & 2,43 & 2,49 & 2,55 & 2,61 & 2,68 & 2,74 \\
\hline Bangun Rumah @Rp.80 juta (triliun) & 0,73 & 0,75 & 0,77 & 0,79 & 0,81 & 0,83 & 0,85 & 0,87 & 0,89 & 0,91 \\
\hline Perbaikan Rumah @Rp.50 juta (triliun) & 0,73 & 0,75 & 0,77 & 0,79 & 0,81 & 0,83 & 0,85 & 0,87 & 0,89 & 0,91 \\
\hline \multirow{2}{*}{ Jumlah Unit } & \multicolumn{10}{|c|}{ Tahun Ke- } \\
\hline & 1 & 2 & 3 & 4 & 5 & 6 & 7 & 8 & 9 & 10 \\
\hline KPR @Rp.140 juta (unit) & 15.739 & 16.120 & 16.511 & 16.915 & 17.330 & 17.758 & 18.199 & 18.653 & 19.121 & 19.602 \\
\hline Bangun Rumah @Rp.80 juta (unit) & 9.181 & 9.403 & 9.632 & 9.867 & 10.109 & 10.359 & 10.616 & 10.881 & 11.154 & 11.435 \\
\hline Perbaikan Rumah @Rp.50 juta (unit) & 14.690 & 15.045 & 15.410 & 15.787 & 16.175 & 16.574 & 16.986 & 17.409 & 17.846 & 18.295 \\
\hline Total 3 manfaat & 39.611 & 40.567 & 41.553 & 42.568 & 43.614 & 44.691 & 45.801 & 46.943 & 48.120 & 49.332 \\
\hline
\end{tabular}

Sumber: Hasil Perhitungan Penulis, 2019

Untuk dapat melihat kemungkinan pemanfaatan oleh peserta dengan kategori MBR, akan disandingkan data PNS yang tercatat pada Badan Kepegawaian Negara (BKN) meliputi PNS pusat, propinsi, maupun tingkat kota/kabupaten yang merupakan bagian dari kepesertaan Tapera. Jumlah PNS seluruh Indonesia per tanggal 31 Desember 2018 adalah 4.185.503 orang.

Golongan PNS yang memungkinkan masuk kategori MBR apabila melihat daftar gaji pokok ditambah tunjangan lain adalah PNS golongan I dan II. Jumlah PNS golongan I dan II per tanggal 31 Desember 2018 adalah: 841.856 orang. Dengan demikian peserta PNS memiliki porsi $62 \%$ dari total peserta. Maka secara proposional pula potensi pemanfaatan dana Tapera yang tersedia pada Tabel 4 akan dibagi proposional sebesar 62\% untuk dimanfaatkan oleh peserta PNS (Lihat Tabel 5)

Tabel 5. Potensi Pemanfaatan Dana Tapera untuk PNS

\begin{tabular}{|c|c|c|c|c|c|c|c|c|c|c|}
\hline \multirow{2}{*}{ Jumlah Unit } & \multicolumn{10}{|c|}{ Tahun Ke- } \\
\hline & 1 & 2 & 3 & 4 & 5 & 6 & 7 & 8 & 9 & 10 \\
\hline KPR @Rp.140 juta (unit) & 9.758 & 9.994 & 10.237 & 10.487 & 10.745 & 11.010 & 11.283 & 11.565 & 11.855 & 12.153 \\
\hline Bangun Rumah @Rp.80 juta (unit) & 5.692 & 5.830 & 5.972 & 6.117 & 6.268 & 6.423 & 6.582 & 6.746 & 6.915 & 7.089 \\
\hline Perbaikan Rumah @Rp.50 juta (unit) & 9.108 & 9.328 & 9.554 & 9.788 & 10.028 & 10.276 & 10.531 & 10.794 & 11.064 & 11.343 \\
\hline Total 3 manfaat & 24.559 & 25.152 & 25.763 & 26.392 & 27.041 & 27.709 & 28.396 & 29.105 & 29.834 & 30.586 \\
\hline
\end{tabular}

Sumber: Hasil Perhitungan Penulis,2019

Tabel 5 menunjukkan pemanfaatan dana Tapera untuk PNS sampai dengan tahun ke-10, total manfaat baru mencapai 274.537 unit. Artinya untuk peserta PNS kategori MBR yang berjumlah 841.856 orang, baru selesai memanfaatkan pembiayaan perumahan ini antara $30-40$ tahun. Durasi ini dinilai terlalu lama dan karenanya dipandang tidak layak. 


\section{Asumsi dengan Menambahkan Anggaran Program Subsidi Pembiayaan Perumahan dari APBN.}

Program subsidi pembiayaan KemenPUPR yang telah berjalan sebelumnya adalah:

a. Subsidi Bantuan Uang Muka (SBUM) yang dialokasikan sebesar Rp1,3 trilyun (tahun 2018);

b. Subsidi Selisih Bunga (SSB) yang dialokasikan sebesar Rp2,5 trilyun (tahun 2018); dan

c. Fasilitas Likuiditas Pembiayaan Perumahan (FLPP) yang dialokasikan sebesar Rp2,18 trilyun (tahun 2018).

Dengan menggunakan asumsi Kementerian PUPR sebelumnya, kemudian menambahkan dengan dana program subsidi pembiayaan perumahan APBN, maka perhitungan potensi kepesertaan dan dana Tapera, serta potensi pemanfaatan dana Tapera dalam bentuk tabel adalah sebagai berikut:

Tabel 6. Potensi Kepesertaan dan Dana Tapera (APBN)

\begin{tabular}{|c|c|c|c|c|c|c|c|c|c|c|}
\hline & \multicolumn{10}{|c|}{ Tahun Ke- } \\
\hline & 1 & 2 & 3 & 4 & 5 & 6 & 7 & 8 & 9 & 10 \\
\hline PNS (org) & 4.468 .000 & 4.602 .040 & 4.740 .101 & 4.882 .304 & 5.028 .773 & 5.179 .637 & 5.335 .026 & 5.495 .076 & 5.659 .929 & 5.829 .727 \\
\hline TNI/Polri (org) & 841.000 & 866.230 & 892.217 & 918.983 & 946.553 & 974.949 & 1.004 .198 & 1.034 .324 & 1.065 .354 & 1.097 .314 \\
\hline Pekerja Swasta (org) & 647.476 & 666.900 & 686.907 & 707.515 & 728.740 & 750.602 & 773.120 & 796.314 & 820.203 & 844.809 \\
\hline Pekerja Mandiri (org) & 776.920 & 800.228 & 824.234 & 848.961 & 874.430 & 900.663 & 927.683 & 955.514 & 984.179 & 1.013 .704 \\
\hline \begin{tabular}{|l} 
Total Peserta (org) \\
\end{tabular} & 6.733 .396 & 6.935 .398 & 7.143 .460 & 7.357 .764 & 7.578 .497 & 7.805 .851 & 8.040 .027 & 8.281 .228 & 8.529 .665 & 8.785 .555 \\
\hline Dana Bapertarum - PNS (Rp. triliun) & 1,1 & 1,1 & 1,1 & 1,1 & 1,1 & 1,1 & 1,1 & 1,1 & 1,1 & 1,1 \\
\hline Dana Subsidi APBN (Rp. Triliun) & 5,8 & 5,8 & 5,8 & 5,8 & 5,8 & 5,8 & 5,8 & 5,8 & 5,8 & 5,8 \\
\hline Simpanan Peserta/tahun (Rp. triliun) & 4,55 & 4,69 & 4,83 & 4,97 & 5,12 & 5,27 & 5,43 & 5,60 & 5,76 & 5,94 \\
\hline Total Simpanan (Rp. triliun) & 11,45 & 11,59 & 11,73 & 11,87 & 12,02 & 12,17 & 12,33 & 12,50 & 12,66 & 12,84 \\
\hline Kumulatif Simpanan (Rp. Triliun) & & 23,04 & 34,76 & 46,64 & 58,66 & 70,83 & 83,16 & 95,66 & 108,32 & 121,16 \\
\hline
\end{tabular}

Sumber: Hasil Perhitungan Penulis,2019

Tabel 7. Potensi Pemanfaatan Dana Tapera (APBN)

\begin{tabular}{|c|c|c|c|c|c|c|c|c|c|c|}
\hline \multirow{2}{*}{ Biaya } & \multicolumn{10}{|c|}{ Tahun Ke- } \\
\hline & 1 & 2 & 3 & 4 & 5 & 6 & 7 & 8 & 9 & 10 \\
\hline Total Simpanan (trilyun) & 11,45 & 11,59 & 11,73 & 11,87 & 12,02 & 12,17 & 12,33 & 12,50 & 12,66 & 12,84 \\
\hline Alokasi Dana Pemanfaatan (triliun) & 7,44 & 7,53 & 7,62 & 7,72 & 7,81 & 7,91 & 8,02 & 8,12 & 8,23 & 8,34 \\
\hline KPR @Rp.140 juta (triliun) & 4,47 & 4,52 & 4,57 & 4,63 & 4,69 & 4,75 & 4,81 & 4,87 & 4,94 & 5,01 \\
\hline Bangun Rumah @Rp.80 juta (triliun) & 1,49 & 1,51 & 1,52 & 1,54 & 1,56 & 1,58 & 1,60 & 1,62 & 1,65 & 1,67 \\
\hline Perbaikan Rumah @Rp.50 juta (triliun) & 1,49 & 1,51 & 1,52 & 1,54 & 1,56 & 1,58 & 1,60 & 1,62 & 1,65 & 1,67 \\
\hline \multirow{2}{*}{ Jumlah Unit } & \multicolumn{10}{|c|}{ Tahun Ke- } \\
\hline & 1 & 2 & 3 & 4 & 5 & 6 & 7 & 8 & 9 & 10 \\
\hline KPR @Rp.140 juta (unit) & 31.896 & 32.277 & 32.668 & 33.072 & 33.487 & 33.915 & 34.356 & 34.810 & 35.278 & 35.759 \\
\hline Bangun Rumah @Rp.80 juta (unit) & 18.606 & 18.828 & 19.057 & 19.292 & 19.534 & 19.784 & 20.041 & 20.306 & 20.579 & 20.860 \\
\hline Perbaikan Rumah @Rp.50 juta (unit) & 29.770 & 30.125 & 30.490 & 30.867 & 31.255 & 31.654 & 32.066 & 32.489 & 32.926 & 33.375 \\
\hline Total 3 manfaat & 80.273 & 81.230 & 82.215 & 83.231 & 84.276 & 85.353 & 86.463 & 87.605 & 88.782 & 89.995 \\
\hline
\end{tabular}

Sumber: Hasil Perhitungan Penulis,2019

Tabel 8. Potensi Pemanfaatan Dana Tapera untuk PNS (APBN)

\begin{tabular}{|c|c|c|c|c|c|c|c|c|c|c|}
\hline \multirow{2}{*}{ Jumlah Unit } & \multicolumn{10}{|c|}{ Tahun Ke- } \\
\hline & 1 & 2 & 3 & 4 & 5 & 6 & 7 & 8 & 9 & 10 \\
\hline KPR @Rp.140 juta (unit) & 19.776 & 20.012 & 20.254 & 20.504 & 20.762 & 21.027 & 21.301 & 21.582 & 21.872 & 22.171 \\
\hline Bangun Rumah @Rp.80 juta (unit) & 11.536 & 11.673 & 11.815 & 11.961 & 12.111 & 12.266 & 12.425 & 12.590 & 12.759 & 12.933 \\
\hline Perbaikan Rumah @Rp.50 juta (unit) & 18.457 & 18.677 & 18.904 & 19.138 & 19.378 & 19.626 & 19.881 & 20.143 & 20.414 & 20.693 \\
\hline Total 3 manfaat & 49.769 & 50.362 & 50.973 & 51.603 & 52.251 & 52.919 & 53.607 & 54.315 & 55.045 & 55.797 \\
\hline
\end{tabular}

Sumber: Hasil Perhitungan Penulis, 2019 
Untuk pemanfaatan bagi PNS golongan MBR dengan subsidi APBN (Tabel 8), setelah dihitung secara proposional maka PNS dengan kategori MBR yang mendaftar kepesertaan Tapera pada tahun ini baru dapat memanfaatkan pembiayaan perumahan $15-20$ tahun mendatang. Durasi inipun dinilai terlalu lama dan tidak layak.

\section{Implikasi Tapera bagi Kebutuhan Perumahan MBR Nasional}

Potensi pemanfaatan dana Tapera yang telah dihitung baik yang bersumber hanya dari simpanan masyarakat, maupun yang bersumber dari simpanan masyarakat dan subsidi APBN jauh dibawah kebutuhan perumahan MBR nasional, yakni 11 juta rumah tangga. Angka ini merupakan campuran antara masyarakat berpenghasilan atas, menengah, dan rendah. Dalam RPJMD Pemprov DKI Jakarta 2017-2022, perhitungan asumsi kebutuhan perumahan rumah tangga MBR sebesar 50\% dari total kebutuhan perumahan. Mengambil asumsi yang sama secara nasional, angka proporsi rumah tangga MBR sebesar 50\% dari total kebutuhan perumahan yakni sebesar 5,5 juta rumah tangga. (Lihat Tabel 9)

Tabel 9. Potensi Pemanfaatan Dana Tapera VS Kebutuhan Perumahan MBR

\begin{tabular}{|c|c|c|}
\hline \multicolumn{2}{|c|}{ Potensi Pemanfaatan Dana Tapera } & Kebutuhan Perumahan MBR \\
\hline $\begin{array}{c}\text { Sumber : Simpanan } \\
\text { masyarakat }\end{array}$ & $\begin{array}{c}\text { Sumber : Simpanan } \\
\text { masyarakat }+ \text { Subsidi APBN }\end{array}$ & $\begin{array}{c}\text { (nasional) } \\
1 \text { rumah tangga }=1 \text { unit }\end{array}$ \\
\hline 39.611 unit $(1: 139)$ & 80.273 unit $(1: 69)$ & 5.500 .000 unit \\
\hline
\end{tabular}

Sumber: Hasil Perhitungan Penulis, 2019

Perbandingan potensi pemanfaatan dana Tapera dengan kebutuhan perumahan MBR menurut Tabel 9. di atas sangat tinggi, yakni $1: 139$ untuk sumber dana simpanan masyarakat; atau $1: 69$ untuk sumber dana simpanan masyarakat + subsidi APBN. Artinya setiap tahun dari 139 rumah tangga MBR yang memenuhi kategori penerima manfaat dana Tapera, hanya akan diberikan kepada 1 rumah tangga MBR sesuai ketersediaan dana.

Hipotesis 2: Model perhitungan program Tapera yang diterapkan secara nasional menunjukkan hasil yang tidak layak disebabkan, antara lain karena:

- Sama seperti Bapertarum-PNS, Program ini tidak diterapkan secara regional;

- Pengerahan dana peserta dihitung menggunakan UM regional rata-rata nasional;

- Harga rumah mengikuti nilai rata-rata harga rumah subsidi nasional;

- Dana pemanfaatan diberikan kepada kategori MBR yang tidak tepat sasaran; dan

- Belum ada dana pihak ketiga atau Lembaga Pembiayaan Pembangunan Sosial yang dapat dimanfaatkan seperti pemanfaatan dana Tapera.

\section{Penerapan Model Tapera di DKI Jakarta}

Backlog perumahan di DKI Jakarta pada tahun 2015 sebesar 302.324 unit, dengan jumlah rumah tangga sebanyak 2.544.487 kepala keluarga. Sedangkan proyeksi kebutuhan rumah pada tahun 2030 adalah sebesar 644.644 unit, yang terdiri atas: 322.322 rumah sederhana, 212.733 rumah menengah, dan 109.590 rumah mewah, dengan proyeksi jumlah rumah tangga pada tahun 2030 sebesar 2.875.629 kepala keluarga.

Untuk mengatasi kebutuhan perumahan di Provinsi DKI Jakarta, di dalam Rencana Pembangunan Jangka Menengah Daerah (RPJMD) 2017 - 2022 Pemprov DKI Jakarta menargetkan pembangunan 300 ribu unit hunian, baik untuk Masyarakat Berpenghasilan Rendah 
(MBR), Masyarakat Berpenghasilan Menengah (MBM), dan Masyarakat Berpenghasilan Atas (MBA), yang direncanakan berasal dari:

a. APBD: 14.562 unit Rusunawa untuk masyarakat yang terkena relokasi;

b. APBN: 3.222 unit, di antaranya Rumah Susun Pasar Minggu dan Rumah Susun Pasar Rumput untuk MBR;

c. Kompensasi peningkatan KLB: 2.500 unit Rusunawa untuk MBR, yang dibangun oleh Developer swasta pada lahan milik Pemprov, kemudian diserahkan kepada Pemprov;

d. BUMD DKI Jakarta: 14.000 unit termasuk didalamnya Program DP 0 rupiah yang diprioritaskan bagi MBR;

e. Mekanisme Pasar (Private Sector): 218.214 unit bagi MBR, MBM, maupun MBA.

DKI Jakarta, seperti juga kota/kabupaten lainnya di Indonesia memiliki permasalahan dan strategi yang berbeda dalam penyediaan perumahan. Hadirnya Tapera diharapkan menjadi solusi yang sinkron dengan strategi kota/kabupaten dalam upaya menyelesaikan masalah perumahan. Dengan menggunakan asumsi KemenPUPR untuk model potensi kepesertaan dan potensi pemanfaatan dana Tapera, berikut adalah gambaran penerapan Tapera di DKI Jakarta.

Tabel 10. Potensi Kepesertaan dan Dana Tapera (APBD)

\begin{tabular}{|c|c|c|c|c|c|c|c|c|c|c|}
\hline & \multicolumn{10}{|c|}{ Tahun Ke- } \\
\hline & 1 & 2 & 3 & 4 & 5 & 6 & 7 & 8 & 9 & 10 \\
\hline PNS (org) & 66.102 & 68.085 & 70.128 & 72.231 & 74.398 & 76.630 & 78.929 & 81.297 & 83.736 & 86.248 \\
\hline TNI/Polri (org) & - & - & - & - & - & - & - & - & - & - \\
\hline Pekerja Swasta (org) & - & - & - & - & - & - & - & - & - & \\
\hline Pekerja Mandiri (org) & - & - & - & - & - & - & - & - & - & - \\
\hline Total Peserta (org) & 66.102 & 68.085 & 70.128 & 72.231 & 74.398 & 76.630 & 78.929 & 81.297 & 83.736 & 86.248 \\
\hline Dana Bapertarum - PNS (Rp. triliun) & 0,01 & 0,01 & 0,01 & 0,01 & 0,01 & 0,01 & 0,01 & 0,01 & 0,01 & 0,01 \\
\hline Subsidi APBD DKI Jakarta & 3,80 & 3,80 & 3,80 & 3,80 & 3,80 & 3,80 & 3,80 & 3,80 & 3,80 & 3,80 \\
\hline Total Simpanan Peserta/tahun (Rp. triliun) & 0,09 & 0,10 & 0,10 & 0,10 & 0,11 & 0,11 & 0,11 & 0,12 & 0,12 & 0,12 \\
\hline Total Simpanan (Rp. Triliun) & 3,91 & 3,91 & 3,91 & 3,92 & 3,92 & 3,92 & 3,93 & 3,93 & 3,93 & 3,94 \\
\hline Kumulatif Simpanan (Rp. triliun) & 3,91 & 7,82 & 11,73 & 15,65 & 19,57 & 23,50 & 27,42 & 31,35 & 35,29 & 39,22 \\
\hline
\end{tabular}

Sumber: Hasil Perhitungan Penulis, 2019

Tabel 11. Potensi Pemanfaatan Dana Tapera (APBD)

\begin{tabular}{|c|c|c|c|c|c|c|c|c|c|c|}
\hline \multirow{2}{*}{ Biaya } & \multicolumn{10}{|c|}{ Tahun Ke- } \\
\hline & 1 & 2 & 3 & 4 & 5 & 6 & 7 & 8 & 9 & 10 \\
\hline Total Simpanan (Rp. trilyun) & 3,91 & 3,91 & 3,91 & 3,92 & 3,92 & 3,92 & 3,93 & 3,93 & 3,93 & 3,94 \\
\hline Alokasi Dana Pemanfaatan (Rp. triliun) & 2,54 & 2,54 & 2,54 & 2,55 & 2,55 & 2,55 & 2,55 & 2,55 & 2,56 & 2,56 \\
\hline KPR @Rp.184 juta (Rp.triliun) & 1,52 & 1,53 & 1,53 & 1,53 & 1,53 & 1,53 & 1,53 & 1,53 & 1,53 & 1,54 \\
\hline Bangun Rumah @Rp.80 juta (Rp.triliun) & 0,51 & 0,51 & 0,51 & 0,51 & 0,51 & 0,51 & 0,51 & 0,51 & 0,51 & 0,51 \\
\hline Perbaikan Rumah @Rp.50 juta (triliun) & 0,51 & 0,51 & 0,51 & 0,51 & 0,51 & 0,51 & 0,51 & 0,51 & 0,51 & 0,51 \\
\hline \multirow{2}{*}{ Jumlah Unit } & \multicolumn{10}{|c|}{ Tahun Ke- } \\
\hline & 1 & 2 & 3 & 4 & 5 & 6 & 7 & 8 & 9 & 10 \\
\hline KPR @Rp.184 juta (unit) & 8.284 & 8.290 & 8.297 & 8.303 & 8.309 & 8.316 & 8.323 & 8.330 & 8.338 & 8.345 \\
\hline Bangun Rumah @Rp.80 juta (unit) & 6.351 & 6.356 & 6.361 & 6.366 & 6.371 & 6.376 & 6.381 & 6.386 & 6.392 & 6.398 \\
\hline Perbaikan Rumah @Rp.50 juta (unit) & 10.162 & 10.170 & 10.177 & 10.185 & 10.193 & 10.201 & 10.210 & 10.218 & 10.227 & 10.237 \\
\hline Total 3 manfaat & 24.798 & 24.816 & 24.834 & 24.853 & 24.873 & 24.893 & 24.914 & 24.935 & 24.957 & 24.980 \\
\hline
\end{tabular}

Sumber: Hasil Perhitungan Penulis, 2019

Tabel 12. Potensi Pemanfaatan Dana Tapera Vs Kebutuhan Perumahan MBR di DKI Jakarta

\begin{tabular}{ccc}
\hline Potensi Pemanfaatan Dana Tapera & $\begin{array}{c}\text { Kebutuhan Perumahan MBR } \\
\text { DKI Jakarta) } \\
\text { orang }=1 \text { unit }\end{array}$ & (PNS \\
APBD & Simpanan masyarakat + Subsidi & $\mathbf{1 2 . 2 0 9}$ unit \\
\hline $\mathbf{2 4 . 7 9 8}$ unit &
\end{tabular}

Hasil Perhitungan Penulis, 2019 
Perbandingan potensi pemanfaatan dana Tapera dengan kebutuhan perumahan PNS kategori MBR di DKI Jakarta pada tabel 12 di atas menunjukkan angka $1: 0,5$. Artinya, ketersedian dana $2 \mathrm{x}$ lebih besar dari kebutuhan perumahan.

Hipotesis 3: Model Tapera yang diaplikasikan secara regional di DKI Jakarta menunjukkan hasil yang sangat layak. Kebutuhan dana mencukupi untuk pembiayaan perumahan bagi peserta kategori MBR. Hal ini disebabkan, antara lain, karena:

- Pengerahan dana peserta dihitung menggunakan upah minimum regional DKI Jakarta. Jika model ini dihitung secara nasional, perhitungan menggunakan rata-rata upah minimum regional seluruh wilayah di Indonesia;

- Harga rumah mengikuti ketentuan batasan yang ditetapkan Kementerian PUPR untuk rumah susun subsidi di DKI Jakarta;

- Dana pemanfaatan Tapera di DKI Jakarta bagi peserta kategori MBR tepat sasaran. Jika model ini dihitung secara nasional, kategori MBR tidak bisa diseragamkan. Perlu data akurat dan detail tentang kategori MBR tiap kota/daerah agar pemanfaatan dana Tapera tepat sasaran;

- Subsidi APBD yang nilainya diperoleh dari rencana pembiayaan program hunian DP 0 Rupiah. Program Pemerintah Provinsi DKI Jakarta ini hendaknya mampu bersinergi dengan program Tapera Pemerintah Pusat, agar tidak terjadi tumpang tindih beban peserta dan tujuan pemenuhan kebutuhan rumah layak dapat tercapai.

\section{KESIMPULAN DAN SARAN}

\section{Kesimpulan:}

a. Tujuan awal pembentukan BAPERTARUM-PNS, yakni untuk mengatasi keterbatasan kemampuan PNS dalam membayar uang muka dan KPR tidak berhasil. Sebagian besar PNS ternyata memanfaatkan Taperum ini sebagai tabungan masa tua/pensiun;

b. Model Tapera yang diaplikasikan secara nasional tidak menjadi solusi terhadap keterjangkauan pembiayaan perumahan bagi MBR;

c. Sedangkan Model Tapera yang diaplikasikan secara regional tampaknya lebih layak dan dapat menjadi solusi terhadap keterjangkauan pembiayaan perumahan bagi MBR.

\section{Saran:}

a. Diperlukan kolaborasi, koordinasi, dan sinkronisasi para pemangku kepentingan (Pemerintah, Pengembang perumahan, Badan pengelola program perumahan, Institusi keuangan) di bidang perumahan pada tingkat nasional/ provinsi/ kabupaten/kota untuk menjadikan Tapera ini sebagai wadah terpusat dalam menghimpun dan menyediakan dana untuk pembiayaan perumahan yang layak dan terjangkau bagi MBR;

b. Tapera harus menjadi Program Strategis Nasional di bidang pembiayaan perumahan dan diaplikasikan secara regional;

c. Penerapan Tapera secara regional diseluruh kota/daerah di Indonesia hendaknya disesuaikan dengan "City Housing Strategy" karena setiap kota atau daerah memiliki masalah dan strategi yang berbeda dalam sistem penyediaan perumahan;

d. Perlunya data akurat terhadap kelompok Masyarakat Berpenghasilan Rendah (MBR) di setiap kota dan daerah, agar pemanfaatan dana Tapera tepat sasaran. 


\section{REFERENSI}

Bappenas. (2017). Kebijakan Nasional Pembangunan Perumahan dan Permukiman. Jakarta: Mei.

Damayanti, R. (2016). “Aktualisasi Kesejahteraan Sosial Melalui Undang-Undang Nomor 4 Tahun 2016 Tentang Tabungan Perumahan Rakyat (TAPERA)". Jurnal Universitas Negeri Semarang. Volume 2 Nomor 1: 259-368.

Direktorat Jenderal Penyediaan Perumahan KemenPUPR.. (2018).'Kebijakan Penyediaan Perumahan bagi Generasi Milenial." Makalah yang dibawakan pada Real Estate Talk\#4, Universitas Tarumanagara, September.

Fahmi, E. (2018). Pendekatan Penelitian Kualitatif dalam Kajian Perkotaan dan Wilayah. Monografi. Jakarta: Universitas Tarumanagara.

Gulo, W. (2010). Metodologi Penelitian. Jakarta: Grasindo.

Kurniati, N. (2014). "Pemenuhan Hak atas Perumahan dan Kawasan Permukiman yang Layak dan Penerapannya Menurut Kovenan Internasional tentang Hak-hak Ekonomi, Sosial, dan Budaya di Indonesia." Padjadjaran Jurnal Ilmu Hukum. Volume 1 - No.1. Indonesia Property Watch. (2016). "Ini Catatan Indonesia Property Watch atas UU Tapera." (On-line). Tersedia di www.berita Hukum Online.com. (26 Februari).

Maslow, A. H. (1954). Motivation and Personality. Reprint from the English Edition by Harper \& Row, Publisher.

Santoso, Jo. et. al. (2002). Sistem Perumahan Sosial di Indonesia. Universitas Indonesia dan Ikatan Ahli Perencanaan (IAP): Center for Urban Studies (Pusat Studi Perkotaan).

Santoso, J. (2002). Koalisi untuk Perumahan Sosial. Pusat Studi Metropolitan-Centropolis, Jakarta.

Santoso, J. (2004). Catatan Mengenai Dasar-Dasar Pengembangan Sistem Perumahan Sosial. Jakarta: Pusat Studi Metropolitan (CENTROPOLIS) Universitas Tarumanagara dan Ikatan Ahli Perencanaan (IAP) Indonesia. 
